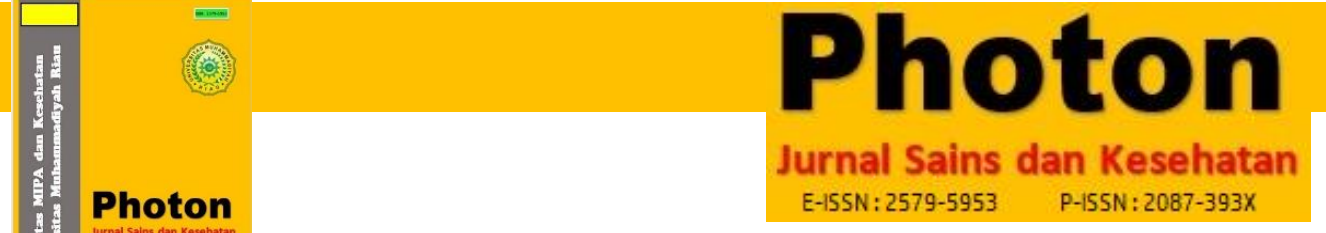

http://ejurnal.umri.ac.id/inde

\title{
Faktor-Faktor Resiko Yang Berhubungan Dengan Kejadian Skizofrenia Di Rumah Sakit Jiwa Tampan Pekanbaru
}

\author{
Chairil, Intan \\ Keperawatan FMIPA Kesehatan, Universitas Muhammadiyah Riau \\ Correspondence Email : chairil@umri.ac.id
}

\begin{abstract}
Background: Schizophrenia is a type of serious mental illness or disorder or chronic mental disorder that can reduce the quality of human life. The incidence of schizophrenia in the Tampan Pekanbaru Mental Hospital was 448 cases in 2020. The purpose of this study was to identify and explain the most influential risk factors for the incidence of schizophrenia at the Tampan Pekanbaru Mental Hospital.Methods: This type of research is analytic observational with a case control approach with a total sample of 52 cases and 52 controls. Case and control sampling technique used simple random sampling. Analysis of the data used is univariate analysis, bivariate using Chi Square test, the study was carried out on February 12 to March 16, 2020. Results: The risk factors associated with the incidence of schizophrenia at the Tampan Pekanbaru Mental Hospital are family history $(\mathrm{p}=0.010$; $\mathrm{aOR}=3,06895 \% \mathrm{CI}=1,371-6,869)$. While the variables that are not related to the incidence of schizophrenia are work history, marital status $(p=0,228$; $a O R=1,71695 \% C I=0,803-3,668)$.
\end{abstract}

Keywords: Schizophrenia, risk factors for schizophrenia

\begin{abstract}
Abstrak
Latar belakang: Skizofrenia merupakan salah satu jenis penyakit atau gangguan kejiwaan yang serius atau gagguan mental kronis yang dapat menurunkan kualitas hidup manusia. Kejadian skizofrenia di Rumah Sakit Jiwa Tampan Pekanbaru sejumlah 450 kasus pada tahun 2020, Tujuan penelitian ini adalah untuk mengetahui dan menjelaskan faktor resiko yang paling berpengaruh dengan kejadian skizofrenia di Rumah Sakit Jiwa Tampan Pekanbaru. Metode Jenis penelitian ini adalah observasional analitik dengan pendekatan case control dengan jumlah sampel sebanyak 52 kasus dan 52 kontrol. Teknik sampling kasus dan kontrol menggunakan simple random sampling. Analisa data yang digunakan adalah analisa univariat, bivariat menggunakan uji Chi Square, Penelitian dilaksanakan pada 12 Februari sampai 16 Maret 2020. Hasil : Faktor risiko yang hubungan dengan kejadian skizofrenia di Rumah Sakit Jiwa Tampan Pekanbaru yaitu riwayat keluarga ( $\mathrm{p}=0,010$; aOR=3,068 95\%CI=1,371- 6,869). Sedangkan variabel yang tidak berhubungan dengan kejadian skizofrenia yaitu riwayat pekerjaan, status pernikahan ( $\mathrm{p}=0,228$; $\mathrm{aOR}=1,71695 \% \mathrm{CI}=0,803-3,668)$.
\end{abstract}

Kata kunci : Skizofrenia, faktor risiko skizofrenia

Received: September 2021, Accepted : November 2021 - Jurnal Photon Vol.12 No.1

DOI : https://doi.org/10.37859/jp.v12i1.2568

PHOTON is licensed under a Creative Commons Attribution-ShareAlike 4.0 International License 


\section{http://ejurnal.umri.ac.id/inde}

\section{Intorduction}

Berbagai masalah kesehatan sering bermunculan karena kondisi kesehatan mental dan pikiran yang tidak terkendali. Masalah yang mengancam kesehatan jiwa salah satunya adalah Skizofrenia. Skizofrenia adalah gangguan parah pikiran. Sekitar 75\% dari pasien dengan pengalaman skizofrenia halusinasi pendengaran dan banyak dari pasien ini tidak menanggapi jangka panjang terapi antipsikotik. Hal ini dapat dilihat dari semakin banyaknya laporan bahwa halusinasi yang tidak segera diberikan terapi akan menimbulkan masalah yang lebih buruk (Zainuddin \& Hashari, 2019). Berdasarkan data World Health Organization (WHO), memperkirakan 450 juta orang mengalami gangguan mental, sekitar $10 \%$ orang dewasa mengalami gangguan jiwa saat ini dan $25 \%$ penduduk diperkirakan akan mengalami gangguan jiwa pada usia tertentu dimasa hidupnya (Zainuddin \& Hashari, 2019).

Di Indonesia, dengan berbagai faktor biologis, psikologis dan sosial dengan keanekaragaman penduduk, maka jumlah kasus gangguan jiwa terus bertambah yang berdampak pada penambahan beban negara dan penurunan produktivitas manusia untuk jangka panjang.

Angka kejadian skizofrenia di Rumah Sakit Jiwa Tampan Pekanbaru Provinsi Riau bulan JanuariDesember 2020 dengan jumlah 1.848 menurut data rekam medik yang ada di Rumah Sakit Jiwa Tampan Pekanbaru Provinsi Riau. Berdasarkan data sekunder yang peneliti dapat melalu data rekam medik di Rumah Sakit Jiwa Tampan Pekanbaru meliputi data pasien rawat inap penderita skizofrenia 4 bulan terakhir 2020 yaitu dari bulan September-Desember dengan jumlah 450 penderita, dan data penunjang lainnya.

Kronologi terjadinya Skizofrenia yaitu dipengaruhi oleh faktor genetik, lingkungan (seperti trauma di masa lalu, masalah interpersonal, masalah keluarga, kegagalan mencapai cita-cita, himpitan ekonomi), pola asuh keluarga yang tidak baik. Faktor-faktor resiko yang berhubungan dengan skizofrenia antara lain faktor internal (riwayat pekerjaan, pendapatan keluarga); faktor eksternal (penyakit penyerta); faktor somatik (riwayat keluarga), faktor psikososial (masalah perkawinan, pola asuh keluarga, gagal mencapai cita- cita), faktor tipe kepribadian (introvet dan ekstrovet). Riwayat keluarga atau faktor keturunan merupakan faktor resiko yang berhubungan dengan kejadian Skizofrenia karena adanya gen resesif pada diri seseorang, perkawinan antara pasangan

Received: September 2021, Accepted : November 2021 - Jurnal Photon Vol.12 No.1 DOI : https://doi.org/10.37859/ip.v12i1.2568

PHOTON is licensed under a Creative Commons Attribution-ShareAlike 4.0 International License 


\section{http://ejurnal.umri.ac.id/inde}

yang memilki gen resesif Skizofrenia akan menghasilkan 36\% diturunkan kepada anak sehingga peran gen dalam kejadian Skizofrenia sangat kompleks dan masih dipengaruhi oleh faktor lain seperti kondisi ketika masih dalam kandungan (Hawari, 2012). Menurut penelitian Agung Wahyudi dan Arulita Ika Fibriana (2016) menunjukkan ada hubungan antara riwayat keluarga atau keturunan dengan kejadian Skizofrenia yang memilki nilai OR 6,234 (95\% CI 2,038-19,069). Riwayat pekerjaan merupakan faktor resiko yang berhubungan dengan Skizofrenia bahwa tidak bekerja dapat menimbulkan stress, depresi dan melemahnya kondisi kejiwaan karena orang yang tidak memiliki pekerjaan menimbulkan rasa ketidakberdayaan dan rasa tidak optimis (tidak percaya diri) terhadap masa depan (Semiun, 2006 dalam Agung 2016). Menurut penelitian Agung Wahyudi dan Arulita Ika Fibriana (2016) menunjukkan ada hubungan antara status pekerjaan dengan kejadian Skizofrenia yang memiliki nilai OR 3,385 (95\% CI 1,180-9,708).

Menerangkan bahwa status perkawinan perlu untuk pertukaran ego atau pertukaran pikiran kepada pasangan dan identifikasi perilaku antara suami dan istri menuju tercapainya kedamaian/keharmonisan Soewadi (2004) dalam Lina Handayani (2015). Status perkawinan merupakan faktor resiko yang berhubungan dengan terjadinya Skizofrenia karena salah satu penyebab stresor psikososial yang dialami oleh sebagian orang diantaranya ditimbulkan dari status perkawinan, mereka yang tidak kawin beresiko lebih tinggi mengalami skizofrenia daripada yang sudah kawin (Simanjuntak, 2008 dalam Agung Wahyudi, 2016) dengan nilai OR 4,747 (95\% CI 1,57514,312).

\section{The Methods Desain Penelitian}

Desain penelitian ini merupakan penelitian epidemiologik analitik dan menggunakan desain case control (kasus kontrol). Penelitian case control (kasus kontrol) adalah suatu penelitian survei analitik yang menyangkut bagaimana faktor resiko dipelajari dengan menggunakan retrospective, dengan kata lain efek (penyakit atau status Kesehatan) diidentifikasi pada saat ini, kemudian faktor risiko di identifikasi ada atau terjadinya pada waktu yang lalu. Pada penelitian ini dilakukan pendekatan retrospective yang diawali dengan mengamati pada kelompok kasus (Skizofrenia), kemudian dilanjutkan dengan kelompok pembanding kontrol (pada pasien gangguan jiwa yang tidak terdiagnosa skizofrenia).

Received: September 2021, Accepted : November 2021 - Jurnal Photon Vol.12 No.1 DOI : https://doi.org/10.37859/ip.v12i1.2568

PHOTON is licensed under a Creative Commons Attribution-ShareAlike 4.0 International License 


\section{http://ejurnal.umri.ac.id/inde}

\section{Tempat dan Waktu Penelitian}

Lokasi Penelitian : Penelitian ini dilakukan di Rumah Sakit Jiwa Tampan Pekanbaru Provinsi Riau

Waktu Penelitian : Penelitian ini akan dilaksanakan pada bulan Maret - April 2021

\section{Populasi dan Sampel}

Populasi adalah wilayah generalisasi yang terdiri atas objek/subjek yang mempunyai kualitas dan karakteristik tertentu yang telah ditentukan oleh peneliti untuk dipelajari dan kemudian ditarik kesimpulannya, populasi bukan hanya orang, tetapi juga objek dan benda-benda alam yang lain (Sugiyono, 2017).

Populasi dalam penelitian ini dibagi menjadi dua yaitu :

1. Populasi Target

Populasi target adalah populasi yang menjadi sasaran akhir penerapan hasil penelitian (Notoatmodjo, 2012). Populasi target pada penelitian ini adalah seluruh data penderita gangguan jiwa tapi tidak terdiagnosa skizofrenia di Rumah Sakit Jiwa Tampan Pekanbaru.

2. Populasi Studi

Populasi studi atau populasi terjangkau adalah bagian dari populasi target yang dapat dijangkau oleh peneliti (Notoatmodjo, 2012). Populasi studi dalam penelitian ini yaitu semua penderita skizofrenia yang berada di Rumah Sakit Jiwa Tampan Pekanbaru dan diabgi dua kelompok, yaitu :

a) Kasus

Semua pasien yang telah didiagnosis Skizofrenia berdasarkan rekam medik pasien yang berada di Rumah Sakit Jiwa Tampan Pekanbaru, dalam penelitian ini kasus berjumlah 1.848 Penderita

b) Kontrol

Seluruh data penderita gangguan jiwa yang tidak terdiagnosa skizofrenia di Rumah Sakit Jiwa Tampan Pekanbaru, dalam penelitian ini berjumlah 2.143 penderita

3. Sampel

Sampel adalah bagian dari jumlah dan karakteristik yang dimiliki oleh populasi tersebut (Sugiyono, 2017). Pengambilam sampel dalam penelitian ini terdiri dari dua kelompok, yaitu : sampel kelompok kasus dan kelompok kontrol.

1) Sampel Kasus

Received: September 2021, Accepted : November 2021 - Jurnal Photon Vol.12 No.1 DOI : https://doi.org/10.37859/ip.v12i1.2568

PHOTON is licensed under a Creative Commons Attribution-ShareAlike 4.0 International License 


\section{http://ejurnal.umri.ac.id/inde}

Sampel kasus dalam penelitian ini adalah Data jumlah pasien penderita skizofrenia empat bulan kebelakang yaitu dari bulan September-Desember di Rumah Sakit Jiwa Tampan Pekanbaru.

2) Sample Kontrol

Sampel kontrol dalam penelitian ini adalah data jumlah pasien penderita gangguan jiwa empat bulan kebelakang yaitu dari bulan September-Desember di Rumah Sakit Jiwa Tampan Pekanbaru.

\section{A. Besar Sampel}

Penentuan besarnya sampel penelitian menggunakan Odds Ratio hasil dari beberapa penelitian terdahulu atau penelitian sebelumnya tentang beberapa faktor resiko yang berhubungan dengan kejadian skizofrenia. Untuk memenuhi jumlah sampel minimal, penentuan ukuran sampel menggunakan rumus sebagai berikut :

$N=\frac{\left\{\mathrm{Z} \alpha \sqrt{[2 \times \mathrm{P} 2(1-\mathrm{P} 2]}+\mathrm{Z} \beta \sqrt{[P 1(1-P 1)+P 2(1-P 2)]\}^{2}}\right.}{(P 1-P 2)^{2}}$

Keterangan :

$\mathrm{N}=$ Besar sampel

P1 = Proporsi paparan kelompok kasus

P2 = Proporsi paparan kelompok kontrol

$\mathrm{Z} \alpha=$ Tingkat kepercayaan $5 \%$

$\mathrm{Z} \beta=$ Presisi $80 \%$

$\mathrm{OR}=$ Odds Ratio.

Dalam penelitian ini diambil dari OR (Odds Ratio) terkecil yaitu 2,82 (diperoleh dari penelitian Erlina, 2012).

Nilai Odds Ratio beberapa faktor-faktor resiko yang berhubungan dengan kejadian skizofrenia dari beberapa penelitian :

1. Menurut penelitian Agung Wahyudi dan Arulita Ika Fibriana (2016) menunjukkan ada hubungan antara status pekerjaan dengan kejadian Skizofrenia yang memiliki nilai OR 3,385 (95\% CI 1,1809,708).

2. Status perkawinan merupakan faktor resiko yang berhubungan dengan terjadinya Skizofrenia karena salah satu penyebab stresor psikososial yang dialami oleh sebagian orang diantaranya ditimbulkan dari status perkawinan, mereka yang tidak kawin beresiko lebih tinggi mengalami

Received: September 2021, Accepted : November 2021 - Jurnal Photon Vol.12 No.1 DOI : https://doi.org/10.37859/ip.v12i1.2568

PHOTON is licensed under a Creative Commons Attribution-ShareAlike 4.0 International License 


\section{http://ejurnal.umri.ac.id/inde}

skizofrenia daripada yang sudah kawin (Simanjuntak, 2008 dalam Agung Wahyudi, 2016) dengan nilai OR 4,747 (95\% CI 1,575-14,312).

3. Menurut penelitian Agung Wahyudi dan Arulita Ika Fibriana (2016) menunjukkan ada hubungan antara riwayat keluarga atau keturunan dengan kejadian Skizofrenia yang memilki nilai OR 6,234 (95\% CI 2,038-19,069).

$\mathrm{P} 1=\frac{O R}{O R+1}$

$=\frac{3,385}{(3,385+1)}$

$=\frac{3,385}{(4,385)}$

$\mathrm{P} 1=0,771$

$$
\begin{aligned}
P 1= & \frac{\mathrm{P} 1}{\mathrm{OR}(1-\mathrm{P} 1)+P 1} \\
& =\frac{0,771}{3,385(1-0,771)+0,771} \\
& =\frac{0,771}{3,385(0,229)+0,771} \\
& =\frac{0,771}{0,775+0,771} \quad \mathrm{P} 2=0,5
\end{aligned}
$$

Dimasukan rumus :

$N=\frac{\left\{\mathrm{Z} \alpha \sqrt{[2 \times \mathrm{P} 2(1-\mathrm{P} 2]}+\mathrm{Z} \beta \sqrt{[P 1(1-P 1)+P 2(1-P 2)]\}^{2}}\right.}{(P 1-P 2)^{2}}$

$N=\frac{\left\{1,96 \sqrt{[2 \times 0,5(1-0,5]}+\mathrm{Z} \beta \sqrt{[0,771(1-0,771)+0,5(1-0,5)]\}^{2}}\right.}{(0,771-0,5)^{2}}$

$N=\frac{\{1,96 \sqrt{0,5}}{+0,842 \sqrt{[0,771(0,229)+P 2(0,25)]\}^{2}}}-$

$N=\frac{\{1,960,707}{+0,842 \sqrt{[0,176(0,25]\}^{2}}}$

$N=\frac{\{1,385+0,842(0652)\}^{2}}{0,073}$

$\mathrm{N}=\frac{\{1,385+0,548\}^{2}}{0,073}$

$\mathrm{N}=\frac{\{1,933\}^{2}}{0,073}$

$\mathrm{N}=\frac{\{1,385+0,842(0652)\}^{2}}{0,073}$

$\mathrm{N}=\frac{3,736}{0,073} \mathrm{~N}=52$

Received: September 2021, Accepted : November 2021 - Jurnal Photon Vol.12 No.1 DOI : https://doi.org/10.37859/ip.v12i1.2568

PHOTON is licensed under a Creative Commons Attribution-ShareAlike 4.0 International License 


\section{http://ejurnal.umri.ac.id/inde}

Jadi besar sampel penelitian ini yang diperlukan untuk kasus dan kontrol 1:1 yang masing- masing sebanyak 52 kasus dan 52 kontrol.

\section{B. Teknik Sampling}

Teknik sampling adalah Teknik pengambilan sampel. Teknik pengambilan sampel dalam penelitian ini adalah menggunakan probability sampling dengan jenis simple random sampling. Simple random sampling yaitu metode pencuplikan sampel secara acak dimana masing-masing subjek atau unit memiliki peluang yang sama dan independent untuk terpilih menjadi sampel (Sugiyono, 2014).

\section{Instrument Penelitian}

Alat bantu yang dipilih dan digunakan oleh peneliti dalam kegiatannya mengumpulkan informasi atau data tentang variabel yang sedang di teliti (Subrata, 2008)

\section{Teknik Pengumpulan Data}

Cara pengumpulan data Pengumpulan data sekunder diperoleh dari laporan rekapitulasi Rumah Sakit Jiwa Tampan Pekanbaru.

\section{E. Cara Pengumpulan Data}

1. Data Sekunder

Data ini merupakan data penunjang kelengkapan data primer. Data sekunder diperoleh melalui jurnal, studi pustaka yaitu buku-buku yang berkaitan dengan masalah yang diteliti, internet dan data-data lain yang mendukung dokumentasi, dan berbagai sumber lainnya. Data sekunder dalam penelitian ini yaitu jumlah penderita Skizofrenia, jumlah penderita gangguan jiwa karakteristik responden berdasarkan usia, jenis kelamin, status pernikahan, Riwayat keluarga, Riwayat pekerjaan yang dipeoleh dari Rumah Sakit Jiwa Tampan Pekanbaru.

\section{F. Analisa Data}

1. Analisa Univariat

Analisa univariat bertujuan untuk menjelaskan atau mendeskripsikan karakteristik setiap variabel penelitian. Analisis ini menghasilkan distribusi frekuensi dan presentase dari tiap variable. Analisis untivariat ini yaitu dari Riwayat keluarga, Riwayat pekerjaan, dan status perkawinan, dengan rumus ;

Received: September 2021, Accepted : November 2021 - Jurnal Photon Vol.12 No.1 DOI : https://doi.org/10.37859/ip.v12i1.2568

PHOTON is licensed under a Creative Commons Attribution-ShareAlike 4.0 International License 


\section{http://ejurnal.umri.ac.id/inde}

$$
P=\frac{x}{n} \times 100
$$

Keterangan :

P : Presentase

$\mathrm{X}$ : jumlah kategori masing-masing variabel

$\mathrm{n}$ : Jumlah responden

\section{Analisa Bivariat}

Analisa bivariat dilakukan dua tahap yang diduga berhubungan atau berkorelasi. Analisa bivariat dilakukan setelah ada perhitungan Analisa univariat. Analisa bivariat hanya menghasilkan hubungan variabel independen dengan variabel dependen dengan uji satistik sesuai dengan skala data pada variabel. Penelitian ini menggunakan data nominal pada variabel independent dan variabel dependent dengan hipotesis asosiatif sehingga uji statistik yang digunakan adalah uji koefesien kontingensi dan chi square. Dari hasil uji statistik ini akan dapat disimpulkan adanya hubungan dua variabel dalam penelitian ini bermakna atau tidak. Teknik ini mempunyai kaitan erat dengan chi square yang digunakan untuk menguji hipotesis komparatif sampel independent.

Rumus chi kuadrat dicari dengan rumus :

$$
X^{2}=\sum_{i}^{k} \frac{(0-E)^{2}}{E}
$$

Rumus Koefisisen kontigensi :

$$
c=\sqrt{\frac{x^{2}}{N+x^{2}}}
$$

Keterangan ;

$\mathrm{O}=$ Frekuensi Observasin

$\mathrm{E}=$ Frekuensi eksplantasi/ harapan

\section{Result and Discussion}

Hasil penelitian yang dilakukan pada tanggal 16 Februari - 12 Maret 2021 dengan jumlah responden 104 orang dengan menggunakan data rekam medik di Rumah Sakit Jiwa Tampan Pekanbaru untuk mengetahui faktor - faktor resiko yang berhubungan dengan kejadian skizofrenia di Rumah Sakit Jiwa Tampan Pekanbaru di dapat data sebagai berikut :

Received: September 2021, Accepted : November 2021 - Jurnal Photon Vol.12 No.1 DOI : https://doi.org/10.37859/ip.v12i1.2568

PHOTON is licensed under a Creative Commons Attribution-ShareAlike 4.0 International License 


\section{Photon \\ Jurnal Sains dan Kesehatan \\ E-15SN: 2579-5953 P-15SN : 2087-393X}

\section{http://ejurnal.umri.ac.id/inde}

\section{A. Data Umum}

Data umum akan menyajikan karakteristik responden penelitian berdasarkan Jenis kelamin responden, status perkawinan.

1. Karateristik responden berdasarkan jenis kelamin

Tabel 1. Distribusi frekuensi karakteristik responden berdasarkan jenis kelamin di Sakit Jiwa Tampan Pekanbaru.

\begin{tabular}{llrrrrrr}
\hline No. & $\begin{array}{l}\text { Jenis } \\
\text { Kelamin }\end{array}$ & \multicolumn{2}{c}{ Kasus } & \multicolumn{2}{c}{ Kontrol } & \multicolumn{2}{c}{ Total } \\
\cline { 3 - 8 } & Jumlah & $\begin{array}{c}\text { Persentase } \\
\text { (\%) }\end{array}$ & Jumlah & $\begin{array}{c}\text { Persentase } \\
\text { (\%) }\end{array}$ & Jumlah & $\begin{array}{c}\text { Persentase } \\
\text { (\%) }\end{array}$ \\
\hline 1. & Laki-laki & 25 & 48,1 & 17 & 32,7 & 42 & 40,4 \\
2. & Perempuan & 27 & 51,9 & 35 & 67,3 & 62 & 59,6 \\
\hline Total & & 52 & 100,0 & 52 & 100,0 & 104 & 100,0 \\
\hline
\end{tabular}

Berdasarkan tabel 1 di atas, dapat diketahui bahwa presentase responden dengan jenis kelamin lakilaki pada kasus sebanyak 25 orang $(48,1 \%)$ lebih besar daripada kelompok kontrol sebanyak 17 orang $(32,7 \%)$.

2. Karakteristik responden berdasarkan status pernikahan

Tabel 2. Distribusi frekuensi karakteristik responden berdasarkan status pernikahan di Rumah Sakit Jiwa Tampan Pekanbaru.

\begin{tabular}{|c|c|c|c|c|c|c|}
\hline \multirow{2}{*}{$\begin{array}{c}\text { Status } \\
\text { Pernikahan }\end{array}$} & \multicolumn{2}{|c|}{ Kasus } & Kontrol & \multicolumn{3}{|c|}{ Total } \\
\hline & Jumlah & sentase (\%) & Jumlah & 'sentase (\%) & Jumlah & sentase (\%) \\
\hline $\begin{array}{l}\text { Belum } \\
\text { menikah }\end{array}$ & 25 & 48,1 & 20 & 38,5 & 45 & 43,3 \\
\hline \multirow[t]{2}{*}{ Menikah } & 27 & 51,9 & 32 & 61,5 & 59 & 56,7 \\
\hline & 52 & 100,0 & 52 & 100,0 & 104 & 100,0 \\
\hline
\end{tabular}

Berdasarkan tabel 2 diatas, dapat diketahui bahwa presentase responden dengan status pernikahan belum menikah pada kasus sebanyak 25 orang $(48,1 \%)$ lebih besar daripada kelompok kontrol sebanyak 20 orang $(38,5 \%)$.

Received: September 2021, Accepted : November 2021 - Jurnal Photon Vol.12 No.1 DOI : https://doi.org/10.37859/jp.v12i1.2568

PHOTON is licensed under a Creative Commons Attribution-ShareAlike 4.0 International License 


\section{http://ejurnal.umri.ac.id/inde}

B. Data Khusus

Data khusus akan menyajikan data karakteristik responden terkait dengan variabel bebas (Riwayat keluarga, Riwayat pekerjaan dan Status pernikahan) serta variabel terikat kejadian skizofrenia.

1. Karakteristik responden berdasarkan Riwayat keluarga

Tabel 3. Distribusi frekuensi karakteristik responden berdasarkan Riwayat keluarga di Sakit Jiwa Tampan Pekanbaru.

\begin{tabular}{|c|c|c|c|c|c|c|c|}
\hline \multirow[t]{2}{*}{ No. } & \multirow{2}{*}{$\begin{array}{c}\text { Riwayat } \\
\text { Keluarga }\end{array}$} & \multicolumn{2}{|c|}{ Kasus } & Kontrol & \multicolumn{3}{|c|}{ Total } \\
\hline & & Jumlah & $\begin{array}{c}\text { Persentase } \\
(\%)\end{array}$ & Jumlah & $\begin{array}{c}\text { Persentase } \\
(\%)\end{array}$ & Jumlah & $\begin{array}{c}\text { Persentase } \\
(\%)\end{array}$ \\
\hline \multirow[t]{2}{*}{1.} & Ada & & & & & & \\
\hline & $\begin{array}{l}\text { Riwayat } \\
\text { Keluarga }\end{array}$ & 36 & 69,2 & 22 & 42,3 & 58 & 55,7 \\
\hline 2. & $\begin{array}{l}\text { Tidak Ada } \\
\text { Riwayat } \\
\text { Keluarga }\end{array}$ & 16 & 30,8 & 30 & 57,7 & 46 & 44,3 \\
\hline Total & & 52 & 100,0 & 52 & 100,0 & 104 & 100,0 \\
\hline
\end{tabular}

Berdasarkan tabel 3 diatas, dapat diketahui bahwa presentase responden dengan Riwayat keluarga skizofrenia pada kasus sebanyak 36 orang $(69,2 \%)$ lebih besar daripada kelompok kontrol sebanyak $22(42,3 \%)$

2. Karakteristik responden berdasarkan Riwayat pekerjaan

Tabel 4. Distribusi frekuensi karakteristik responden berdasarkan Riwayat pekerjaan di Sakit Jiwa Tampan Pekanbaru.

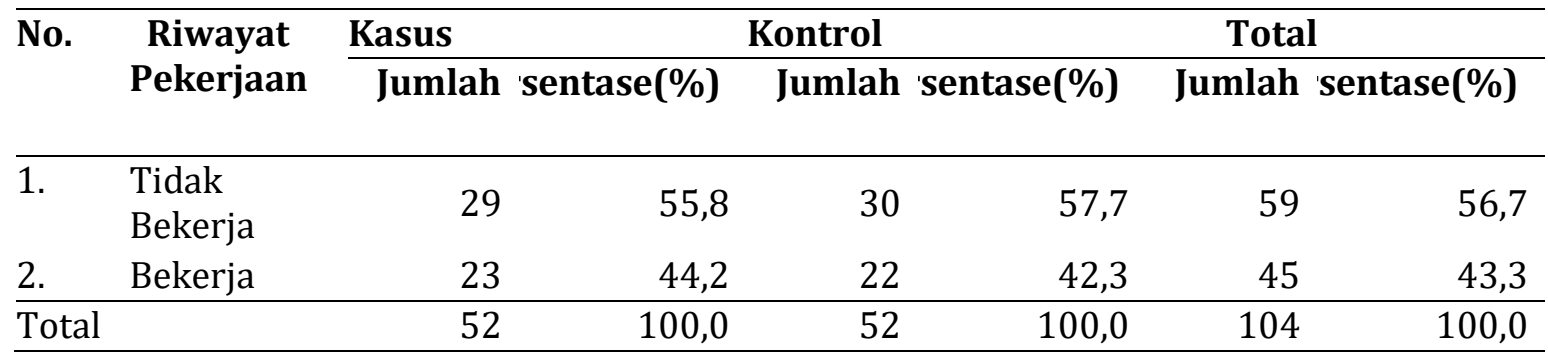

Berdasarkan table 4 di atas, dapat diketahui bahwa presentase responden dengan status pekerjaan tidak bekerja pada kasus sebanyak 29 orang (55,8\%) lebih kecil daripada kelompok kontrol sebanyak 30 orang $(57,7 \%)$.

Received: September 2021, Accepted : November 2021 - Jurnal Photon Vol.12 No.1 DOI : https://doi.org/10.37859/ip.v12i1.2568

PHOTON is licensed under a Creative Commons Attribution-ShareAlike 4.0 International License 


\section{http://ejurnal.umri.ac.id/inde}

3. Karakteristik responden berdasarkan status pernikahan

Tabel 5. Distribusi frekuensi karakteristik responden berdasarkan status pernikahan di Sakit Jiwa Tampan Pekanbaru.

\begin{tabular}{|c|c|c|c|c|c|c|}
\hline \multirow{2}{*}{$\begin{array}{c}\text { Status } \\
\text { Pernikahan }\end{array}$} & \multicolumn{2}{|c|}{ Kasus } & \multicolumn{2}{|l|}{ Kontrol } & \multicolumn{2}{|c|}{ Total } \\
\hline & Jumlah & sentase(\%) & Jumlah & sentase(\%) & Jumlah & sentase $(\%)$ \\
\hline $\begin{array}{l}\text { Tidak } \\
\text { Menikah }\end{array}$ & 25 & 48,1 & 20 & 38,5 & 45 & 43,3 \\
\hline Menikah & 27 & 51,9 & 32 & 61,5 & 59 & 56,7 \\
\hline & 52 & 100,0 & 52 & 100,0 & 104 & 100,0 \\
\hline
\end{tabular}

Berdasarkan table 5 diatas, dapat diketahui bahwa presentase responden dengan status pernikahan belum menikah pada kasus sebanyak 25 orang $(48,1 \%)$ lebih besar daripada kelompok kontrol sebanyak 20 orang $(38,5 \%)$.

C. ANALISA BIVARIAT

Analisa bivariat bertujuan untuk mengetahui hubungan dan besarnya nilai odds ratio faktor resiko dan digunakan untuk mencari hubungan antara variabel bebas dan variabel terikat dengan uji statistik yang disesuaikan dengan skala data yang ada. Uji statistik yang digunakan chi-square dan penentuan odds ratio (OR) dengan taraf kepercayaan (CI) 95\% dan tingkat kemaknaan 0,05. Berikut adalah hasil analisis bivariat dibawah ini :

Tabel 6. Hubungan antara Riwayat keluarga dengan kejadian skizofrenia di Rumah Sakit Jiwa Tampan Pekanbaru

\begin{tabular}{|c|c|c|c|c|c|c|c|}
\hline \multirow[t]{3}{*}{ Riwayat Keluarga } & \multicolumn{3}{|c|}{ Status } & & \multirow[t]{3}{*}{ OR } & \multirow[t]{3}{*}{$95 \% \mathrm{CI}$} & \multirow[t]{3}{*}{$P$} \\
\hline & \multicolumn{2}{|c|}{ Kasus } & \multicolumn{2}{|c|}{ Kontrol } & & & \\
\hline & $\mathbf{N}$ & $\%$ & $\mathbf{N}$ & $\%$ & & & \\
\hline $\begin{array}{l}\text { Ada Riwayat } \\
\text { Keluarga }\end{array}$ & 36 & 69,2 & 22 & 42,3 & & & \\
\hline $\begin{array}{c}\text { Tidak Ada Riwayat } \\
\text { Keluarga }\end{array}$ & 16 & 30,8 & 30 & 57,7 & 3,06 & $1,37-6,86$ & 0,010 \\
\hline Total & 52 & 100,0 & 52 & 100,0 & & & \\
\hline
\end{tabular}

Berdasarkan tabel 6 diatas, dapat diketahui bahwa presentase responden dengan Riwayat keluarga skizofrenia pada kasus sebanyak 36 orang (69,2\%) lebih besar daripada kelompok kontrol sebanyak

Received: September 2021, Accepted : November 2021 - Jurnal Photon Vol.12 No.1 DOI : https://doi.org/10.37859/ip.v12i1.2568

PHOTON is licensed under a Creative Commons Attribution-ShareAlike 4.0 International License 


\section{http://ejurnal.umri.ac.id/inde}

30 orang $(57,7 \%)$. Jadi proporsi riwayat keluarga Skizofrenia lebih banyak pada kasus dibanding pada kontrol. Hasil analisis uji chi square diperoleh nilai $p$ value $(0,010)<\alpha(0,05)$ maka $\mathrm{H}_{1}$ diterima, yang menunjukan bahwa riwayat keluarga Skizofrenia memiliki hubungan yang bermakna dengan kejadian Skizofrenia. Nilai risiko dapat dilihat dari nilai OR yaitu 3,06 yang berarti faktor risiko kejadian Skizofrenia. Sendangkan 95\%CI yaitu 1,37 - 6,86 yang berarti tidak melewati angka 1 yang menyatakan ada hubungan.

Tabel 7. Hubungan antara Riwayat pekerjaan dengan kejadian skizofrenia di Rumah Sakit Jiwa Tampan Pekanbaru

\begin{tabular}{|c|c|c|c|c|c|c|c|}
\hline \multirow[t]{3}{*}{ Riwayat Pekerjaan } & \multicolumn{3}{|c|}{ Status } & & \multirow[t]{3}{*}{$\mathbf{O R}$} & \multirow[t]{3}{*}{$95 \% \mathrm{CI}$} & \multirow[t]{3}{*}{$\boldsymbol{P}$} \\
\hline & \multicolumn{2}{|c|}{ Kasus } & \multicolumn{2}{|c|}{ Kontrol } & & & \\
\hline & $\mathbf{N}$ & $\%$ & $\mathbf{N}$ & $\%$ & & & \\
\hline Tidak bekerja & 29 & 55,8 & 30 & 57,7 & & & \\
\hline Bekerja & 23 & 44,2 & 22 & 42,3 & 1,01 & $0.46-2,19$ & 1,000 \\
\hline Total & 52 & 100,0 & 52 & 100,0 & & & \\
\hline
\end{tabular}

Berdasarkan tabel 7 di atas, dapat diketahui bahwa presentase responden dengan status pekerjaan tidak bekerja pada kasus sebanyak 29 orang $(55,8 \%)$ lebih kecil daripada kelompok kontrol sebanyak 30 orang $(57,7 \%)$. Jadi proporsi tidak bekerja lebih banyak pada kontrol dibanding pada kasus. Hasil analisis uji chi square diperoleh nilai $p$ value $(1,000)>\alpha(0,05)$ maka $\mathrm{H}_{1}$ ditolak, yang menunjukan bahwa kategori riwayat pekerjaan tidak memiliki hubungan yang bermakna dengan kejadian Skizofrenia. Nilai risiko dapat dilihat dari nilai OR yaitu 1,01 yang berarti riwayat pekerjaan merupakan faktor protektif kejadian Skizofrenia. Sedangkan 95\% CI yaitu 0,46 - 2,19 yang berarti melewati angka 1 yang menyatakan tidak ada hubungan.

Received: September 2021, Accepted : November 2021 - Jurnal Photon Vol.12 No.1 DOI : https://doi.org/10.37859/ip.v12i1.2568

PHOTON is licensed under a Creative Commons Attribution-ShareAlike 4.0 International License 
Photon

Jurnal Sains dan Kesehatan

E-155N: 2579-5953 P-155N : 2087-393X

\section{http://ejurnal.umri.ac.id/inde}

Tabel 8. Hubungan antara Status Pernikahan dengan kejadian skizofrenia di Rumah Sakit Jiwa Tampan Pekanbaru.

\begin{tabular}{llllll}
\hline Status Pernikahan & \multicolumn{2}{c}{ Status } & OR & \multirow{2}{*}{$95 \% \mathrm{CI}$} & P \\
\cline { 2 - 4 } & & & \\
\cline { 2 - 5 } & $\mathrm{N}$ & $\%$ & $\mathrm{~N}$ & & \\
& & &
\end{tabular}

$\begin{array}{lllll}\text { Belum menikah } & 25 & 48,1 & 20 & 38,5\end{array}$

\begin{tabular}{lrrrrrrr} 
Menikah & 27 & 51,9 & 32 & 61,5 & 1,71 & $0,80-3,66$ & 0,228 \\
\cline { 1 - 5 } Total & $\mathbf{5 2}$ & $\mathbf{1 0 0 , 0}$ & $\mathbf{5 2}$ & $\mathbf{1 0 0 , 0}$ & & & \\
\hline
\end{tabular}

Berdasarkan table 8 diatas, dapat diketahui bahwa presentase responden dengan status pernikahan belum menikah pada kasus sebanyak 25 orang $(48,1 \%)$ lebih besar daripada kelompok kontrol sebanyak 20 orang (38,5\%). Jadi proporsi status pernikahan lebih banyak pada kasus dibanding pada kontrol. Hasil analisis uji chi square diperoleh nilai $p$ value $(0,228)>\alpha(0,05)$ maka $\mathrm{H}_{1}$ ditolak, yang menunjukan bahwa Status pernikahan tidak memiliki hubungan yang bermakna dengan kejadian Skizofrenia. Nilai risiko dapat dilihat dari nilai OR yaitu 1,71 yang berarti faktor risiko kejadian Skizofrenia. Sendangkan 95\%CI yaitu 0,80- 3,66 yang berarti melewati angka 1 yang menyatakan tidak ada hubungan.

Tabel 9. Rangkuman Hasil Analisis Bivariat Faktor - Faktor Resiko yang Berhubungan dengan Kejadian Skizofrenia di Rumah Sakit Jiwa Tampan Pekanbaru.

\begin{tabular}{lllrc}
\hline No. & Variabel & OR & 95\% CI & \multicolumn{1}{c}{ P value } \\
\hline 1. & Riwayat Pekerjaan & 1,011 & $0,465-2,196$ & 1,000 \\
2. & Status Pernikahan & 1,716 & $0,803-3,668$ & 0,228 \\
4. & Riwayat Keluarga & 3,068 & $1,371-6,869$ & $0,010^{* *}$ \\
\hline
\end{tabular}

Dari table 9 di atas dapat diketahui bahwa variabel yang berhubungan dengan kejadian skizofrenia adalah Riwayat keluarga. Hasil penelitian mengenai faktor-faktor resiko yang berhubungan dengan kejadian Skizofrenia pada 52 penderita skizofrenia dan 52 penderita gangguan jiwa berdasarkan data rekam medik di Rumah Sakit Jiwa Tampan Pekanbaru. Berdasarkan Analisa Bivariat, variabel yang terbukti merupakan faktor resiko yang berhubungan dengan kejadian skizofrenia adalah Mayoritas dari Riwayat keluarga.

Received: September 2021, Accepted : November 2021 - Jurnal Photon Vol.12 No.1 DOI : https://doi.org/10.37859/ip.v12i1.2568

PHOTON is licensed under a Creative Commons Attribution-ShareAlike 4.0 International License 


\section{http://ejurnal.umri.ac.id/inde}

Riwayat keluarga atau faktor keturunan merupakan faktor yangberhubungan dengan kejadian Skizofrenia karena adanya gen resesif pada diri seseorang, perkawinan antara pasangan yang memilki gen resesif Skizofrenia akanmenghasilkan 36\% diturunkan kepada anak sehingga peran gen dalam kejadian Skizofrenia sangat kompleks dan masih dipengaruhi oleh faktor lain seperti kondisi ketika masih dalam kandungan (Hawari, 2012).

Berdasarkan hasil penelitian, Agung Wahyudi dan Arulita Ika Fibriana (2016) menunjukkan ada hubungan antara riwayat keluarga atau keturunan dengan kejadian Skizofrenia yang memilki nilai OR 6,23 (95\% CI 2,03-19,06). Secara umum dampak yang ditimbulkan penderita Skizofrenia bagi keluarga antara lain efek emosional (psikologis) yaitu rasa bersalah, dendam, marah, malu, kebingungan dan keputusasaan adalah beberapa emosi yang dirasakan oleh mereka yang terkait dan merawat seseorang dengan Skizofrenia. Orang tua merasabersalah dan marah jika mereka memilki anak dengan Skizofrenia, karena orang tua merasa khawatir bagaimana penyakit tersebut bisa berkembang. Dampak selanjutnya ada efek sosial yaitu memiliki Skizofrenia dapat membuat pekerjaan, menjaga hubungan dan perawatan/pemenuhan kebutuhan pribadi sangat sulit, karena orang-orang dengan Skizofrenia sering berdelusi dan berhalusinasi, mereka merasa sulit untuk mempertahankan pekerjaan, yang menyebabkan tekanan keungan atau himpitan ekonomi pada keluarga yang merawat mereka dan untuk keluarga dengan anggota keluarga Skizofrenia, pengobatan menyebabkan bertambahnya pengeluaran serta bertamhanya biaya hidup. Orang dengan Skizofrenia memerlukan obat, terapi dan kebutuhan hidup lainnya untuk berkembang.

Bagi mereka yang sudah menikah atau dalam hubungan dengan seorang Skizofrenia, kegiatan sederhana dan menyenangkanseperti menghadiri suatu acara resmi ataupun acara liburan menjadi salah satu kekhawatiran ketika penderita Skizofrenia tidak dapat dikendalikan dan bertingkah tidak wajar didepan umum. Efek sosial ini akan yang akan mempengaruhi orang tua atau keluargameliputi; gangguan terhadap rutinitas orang tua atau keluarga dari penderita Skizofrenia, orang tua atau keluaraga akan mengabaikan kebutuhan pribadi, hubungan dengan putra putrinya yang lain akan merasakan perbedaan perlakuan, waktu dengan anak-anaknya yang lain akan berkurang, hubungan dengan pasangan akan kurang harmonis dan adanya konflik yang sering terjadi, adanya pengasingan yaitu banyak stigma negatif dari masyarakat kepada penderita Skizofrenia sehingga orang tua atau

Received: September 2021, Accepted : November 2021 - Jurnal Photon Vol.12 No.1 DOI : https://doi.org/10.37859/jp.v12i1.2568

PHOTON is licensed under a Creative Commons Attribution-ShareAlike 4.0 International License 


\section{http://ejurnal.umri.ac.id/inde}

keluaraga dari penderita enggan untuk terbuka, hubungan dengan saudara yang lain akan mengalami kurangnya komunikasi. Berdasarkan penelitian yang peneliti dapat diketahui bahwa presentase responden dengan status pernikahan belum menikah pada kasus sebanyak 25 orang $(48,1 \%)$ lebih besar daripada kelompok kontrol sebanyak 20 orang $(38,5 \%)$. Hasil analisis uji chi square diperoleh nilai $p$ value $(0,228)>\alpha(0,05)$ maka $\mathrm{H}_{1}$ ditolak, yang menunjukan bahwa Riwayat pernikahan tidak memiliki hubungan yang bermakna dengan kejadian Skizofrenia. Nilai risiko dapat dilihat dari nilai OR yaitu 1,71 yang berarti faktor risiko kejadian Skizofrenia. Sendangkan 95\%CI yaitu $0,80-3,66$.

\section{Conclusion}

Berdasarkan hasil penelitian yang telah dilaksanakan pada tanggal 16 Februari - 12 Maret dengan merekap data rekam medik empat bulan terakhir di 2020 pada penderita skizofrenia dan penderita gangguan jiwa dengan jumlah masing-masing responden yang di ambil dari data sebanyak 52 orang penderita skizofrenia 52 penderita gangguan jiwa. Untuk mengetahui faktor-faktor resiko yang berhubungan dengan kejadian skizofrenia yang telah dipaparkan pada Bab $\mathrm{V}$, sesuai dengan tujuan yang akan dicapai pada penelitian ini, maka dapat disimpulkan bahwa faktor -faktor resiko yang berhubungan dengan kejadian skizofrenia adalah Riwayat keluarga.

Terbukti dengan hasil bahwa presentase responden dengan Riwayat keluarga skizofrenia pada kasus sebanyak 36 orang $(69,2 \%)$ lebih besar daripada kelompok kontrol sebanyak 30 orang $(57,7 \%)$. Hasil analisis uji chi square diperoleh nilai $p$ value $(0,010)<\alpha(0,05)$ maka $\mathrm{H}_{1}$ diterima, yang menunjukan bahwa riwayat keluarga Skizofrenia memiliki hubungan yang bermakna dengan kejadian Skizofrenia. Nilai risiko dapat dilihat dari nilai OR yaitu 3,06 yang berarti faktor risiko kejadian Skizofrenia. Sendangkan 95\%CI yaitu 1,37 - 6,86 yang berarti tidak melewati angka 1 yang menyatakan ada hubungan.

Received: September 2021, Accepted : November 2021 - Jurnal Photon Vol.12 No.1 DOI : https://doi.org/10.37859/ip.v12i1.2568

PHOTON is licensed under a Creative Commons Attribution-ShareAlike 4.0 International License 


\section{http://ejurnal.umri.ac.id/inde}

\section{References}

Cepi Hidayat, Reini Astuti, dan Wulan Novika Ambarsari. 2013. Hubungan Masalah Psikososial Dengan Kejadian Skizofrenia Di Wilayah Kerja Puskesmas Cibeber Kota Cimahi: Jurnal Kesehatan Budi Luhur Cimahi. Vol. 8, No. 3, Hal. 28. Diakses melalui http://stikesbudiluhurcimahi.ac.id

Dahlan, Sopiyudin. 2014. Statistik Untuk Kedokteran dan Kesehatan. Jakarta: Epidemiologi Indonesia.

Devita, AM. 2012. Peran Atypycal Antipsychotic dalam Menurunkan Perilaku Agresif pada Pasien Skizofrrenia. Jurnal Kesehatan. Denpasar: Bagian SMF Fakultas Kedokteran Universitas Udayana. Diakses melalui http://eprints.ums.ac.id

Dinas Kesehatan Kota Pekanbaru. Profil Kesehatan Kota pekanbaru tahun 2020. Diakses melalui http://diskes.pekanbaru.go.id

Erlina. 2010. Determinan Terhadap Timbulnya Skizofrenia pada Pasien Rawat Jalan di Rumah Sakit Jiwa Prof. HB Saanin Padang Sumatera Barat, Berita Kedokteran Masyarakat, Vol. 26, No. 2, Hlm. 71. Diakses melalui https://journal.unnes.ac.id

Handayani, Lina. 2015. Faktor risiko kejadian Skizofrenia di Rumah Sakit Jiwa Grhasia Daerah Istimewa Yogyakarta (DIY). Diakses melalui http://journal.uad.ac.id

Isaacs, Ann. "Keperawatan kesehatan jiwa \& psikiatrik”. Buku Panduan Keperawatan Kesehatan, Jilid 3.

Laksono, Tanjung. 2013. Hubungan antara faktor somatik, psikososial, dan sosio- kultur dengan kejadian skizofrenia di instalasi rawat jalan RSJD Surakarta. Diakses melalui http://eprints.ums.ac.id

Lazuardi Gheafani Astrid. 2015. Hubungan Pola Asuh Orang Tua dengan Kejadian Gangguan Jiwa pada Keluarga di Desa Banaran Galur Kulon Progo. Yogyakarta. Dipetik melalui http://digilib.unisayogya.ac.id.

Putra, I.G.S.S, 2015. Journal Hubungan Antara Tipe Kepribadian Introvert dan Ekstrovert dengan Kejadian Stres Pada Koasisten Angkatan Tahun 2011 Fakultas Kedokteran Universitas Udayana. Diakses melalui http://digilib.unisayogya.ac.id

Riskesdas, Kemenkes. 2018. “ Data Prevalensi Kesehatan Jiwa”. Dipetik melalui http://repository.pkr.ac.id/464/6/BAB\%201\%20Pendahuluan.pdf

Videbeck, S. L. 2010. Psychiatric Mental Health Nursing. Philadelphia: Lippincot Williams \& Wilkins. Dipetik melalui http://jurnal.unmuhjember.ac.id

Received: September 2021, Accepted : November 2021 - Jurnal Photon Vol.12 No.1

DOI : https://doi.org/10.37859/jp.v12i1.2568

PHOTON is licensed under a Creative Commons Attribution-ShareAlike 4.0 International License 


\section{http://ejurnal.umri.ac.id/inde}

Wahyudi, Agung. 2016. Faktor risiko terjadinya Skizofrenia (Studi Kasus di Wilayah Kerja Puskesmas Pati II). Dipetik melalui https://journal.unnes.ac.id

World Health Organizations (WHO). 2013. Skizofrenia. Dipetik melalui http://elib.stikesmuhgombong.ac.id

Yanuar, R. 2012. Analisis Faktor yang Berhubungan dengan Kejadian Gangguan Jiwa di Desa Paringan Kecamatan Jenangan kabupaten Ponorogo. Diakses melalui http://digilib.unisayogya.ac.id

Yosep. 2013. Keperawatan Jiwa Edisi Revisi. Bandung : PT. Refika Aditama 346. Dipetik melalui http://elib.stikesmuhgombong.ac.id

Received: September 2021, Accepted : November 2021 - Jurnal Photon Vol.12 No.1 DOI : https://doi.org/10.37859/ip.v12i1.2568

PHOTON is licensed under a Creative Commons Attribution-ShareAlike 4.0 International License 